\title{
Influence of epidermal growth factor (EGF) supplementation at different times of in vitro maturation of canine oocytes
}

\section{Influência da suplementação do fator de crescimento epidermal (EGF) em diferentes momentos da maturação in vitro de oócitos caninos}

\author{
Leda Maria Costa PEREIRA ${ }^{1}$; Paulo Ricardo de Oliveira BERSANO²; Maria Denise LOPES ${ }^{1}$ \\ ${ }^{1}$ Universidade Estadual Paulista "Júlio de Mesquita Filho", Faculdade de Medicina Veterinária e Zootecnia, \\ Departamento de Reprodução Animal e Radiologia Veterinária, Botucatu - SP, Brazil \\ ${ }^{2}$ Universidade Estadual do Ceará, Faculdade de Veterinária, Fortaleza - CE, Brazil
}

\begin{abstract}
The aim of this study was to evaluate the influence of epidermal growth factor (EGF) on in vitro maturation of canine oocytes at different times of the process. Ovaries were collected from 55 bitches considered healthy and aseptically isolated, immersed in physiological solution $(0.9 \% \mathrm{NaCl})$ and transported under refrigeration. Grade 1 cumulus-oocyte complexes (COCs) were selected and divided into two groups: control group (CG) and treatment group (TG). In CG 698 grade I COCs were placed in 4-well plates containing TCM-199 medium supplemented with $25 \mathrm{mM}$ HEPES, $100 \mathrm{IU} / \mathrm{mL}$ penicillin, 100 $\mathrm{mg} / \mathrm{mL}$ streptomycin, $26 \mathrm{mM}$ sodium bicarbonate, $1.5 \mathrm{mM}$ sodium pyruvate, $2.9 \mathrm{mM}$ sodium lactate pentahydrate, 0.6 $\mathrm{mM}$ cysteine, $0.03 \mathrm{IU} / \mathrm{mL}$ hCG, $0.5 \mu \mathrm{g} / \mathrm{mL} \mathrm{FSH}, 20 \mu \mathrm{g} / \mathrm{mL}$ estrogen at $38.5^{\circ} \mathrm{C}$ in a humidified atmosphere of $5 \% \mathrm{CO}_{2}$ in times of $24 \mathrm{~h}, 48 \mathrm{~h}$, and $72 \mathrm{~h}$. In TG 547 COCs received the same maturation medium plus $10 \mathrm{\eta g} / \mathrm{mL}$ EGF. Logistic regression models (SAS, 2011) were constructed in order to estimate the chances of oocytes being observed at nuclear maturation stages in different culture times ( $24 \mathrm{~h}, 48 \mathrm{~h}$, and $72 \mathrm{~h}$ ). Based on the results found EGF-supplemented medium showed 2.56 times more chances of having an oocyte at metaphase I (M-I) than medium without EGF $(p<0.0001)$. The results of this study demonstrated that the time of $72 \mathrm{~h}$ showed 5.88 times more chances of having an oocyte at metaphase II (M-II) compared to time of $24 \mathrm{~h}(\mathrm{p}=0.0001)$ and 7.69 times more chance than time of $48 \mathrm{~h}(\mathrm{p}=0.0001)$. The chances of finding an oocyte at M-II were also 9.09 times higher in medium supplemented with EGF than in medium without EGF $(\mathrm{p}=0.0001)$. Thus, these results demonstrated the essential importance of EGF at different moments of oocyte maturation, being a key component for the acquisition of meiotic competence in bitches, increasing the M-I and M-II rates.
\end{abstract}

Keywords: EGF. Oocyte. Competence. Bitches.

\section{Resumo}

O objetivo deste estudo foi avaliar a influência do fator de crescimento epidermal (EGF) em diferentes momentos da maturação in vitro de oócitos caninos. Os ovários foram coletados de 55 cadelas consideradas sadias e isolados assepticamente, imersos em solução fisiológica e transportados refrigerados. Os complexos cumulus-oócito (COCs) grau 1 foram selecionados e divididos em dois grupos, denominados grupo controle (GC) e grupo tratamento (GT). No GC, 698 COCs grau I foram cultivados em placas de quatro poços contendo meio TCM-199 suplementado com $25 \mathrm{mM}$ de HEPES, $100 \mathrm{UI} / \mathrm{mL}$ de penicilina, $100 \mathrm{mg} / \mathrm{mL}$ de estreptomicina, $26 \mathrm{mM}$ de bicarbonato de sódio, $1,5 \mathrm{mM}$ de piruvato de sódio, 2,9 $\mathrm{mM}$ de lactato de sódio penta hidratado, 0,6 mM de cisteína, 0,03 UI/mL de hCG, 0,5 $\mu \mathrm{g} / \mathrm{mL}$ de FSH, $20 \mu \mathrm{g} /$ $\mathrm{mL}$ de estrógeno em estufa úmida a $38^{\circ} \mathrm{C}, 5 \%$ de $\mathrm{CO}_{2}$ nos períodos de $24 \mathrm{~h}, 48 \mathrm{~h}$ e $72 \mathrm{~h}$. Já no GT, 547 COCs receberam o mesmo meio de maturação acrescido de $10 \mathrm{\eta g} / \mathrm{mL}$ do EGF. Modelos de regressão logística foram elaborados para estimar as chances do oócito ser observado nos estágios de maturação nuclear em diferentes tempos de cultivo. Com base nos resultados encontrados, o meio suplementado com EGF demonstrou 2,56 vezes mais chances de ter um oócito no estágio de metáfase I (M-I) do que o meio sem EGF ( $\mathrm{p}<0,0001)$. Os resultados desse estudo demonstraram também que o tempo de $72 \mathrm{~h}$ mostrou 5,88 vezes mais chances de ter um oócito no estágio de metáfase II (M-II) do que o tempo de $2 \mathrm{~h}$ ( $\mathrm{p}=$ $0,0001)$ e 7,69 vezes mais chance do que o tempo de $48 \mathrm{~h}(\mathrm{p}=0,0001)$. As chances de se encontrar um oócito em M-II também foram 9,09 vezes maiores no meio suplementado com EGF do que no meio sem EGF ( $p=0,0001$ ). Dessa forma, estes resultados demonstraram a importância essencial do EGF em diferentes momentos da maturação oocitária, sendo componente chave para a aquisição da competência meiótica nas cadelas, aumentando os índices de M-I e M-II.

Palavras-chave: EGF. Oócito. Competência. Cadelas. 
Correspondence to:

Leda Maria Costa Pereira

Universidade Estadual "Júlio de Mesquita Filho",

Departamento de Reprodução Animal e Radiologia

Veterinária, Laboratório de Pequenos Animais e Silvestres

Rua Prof. Doutor Walter Mauricio Correia, s/n

CEP 18618-681, Botucatu, SP, Brazil

e-mail: ledamcp@hotmail.com

Received: 25/05/2017

Approved: 31/08/2017

\section{Introduction}

Reproductive biotechnologies such as in vitro maturation (IVM) or in vitro fertilization (IVF) are essential to produce viable oocytes and embryos that assist in the survival of endangered species. However, the efficiency of these techniques is still very limited in the canine species, with maturation rates varying from $0 \%$ to $58 \%$ for meiosis resumption, and an average $20 \%$ of metaphase II (M-II) (FARSTAD, 2000).

One of the factors that can be considered responsible for the low meiotic competence of canine oocyte is the inefficiency of the culture media. Most of the protocols adopted are based on culture media used in other domestic species, especially cattle, not considering the endocrine and biochemical needs of bitches. The culture medium routinely used in canine oocyte maturation is tissue culture medium 199 (TCM-199). In general, substances found in the follicular fluid, such as proteins, hormones, antioxidants, and growth factors, among others, are added to TCM-199 in order to increase maturation rates and to develop an environment similar to that observed in in vivo experiments. In this scenario the epidermal growth factor (EGF) has shown great benefits in the acquisition of meiotic competence and progression of oocyte maturation in the canine species (BOLAMBA et al., 2002; KIM et al., 2004; PEREIRA et al., 2014)

The EGF family is composed of several members that exert influence on the most varied biological events related to ovarian physiology in mammals, such as the proliferation of granulosa cells, steroidogenesis and oocyte maturation. Growth factors belonging to the EGF family can bind to different types of transmembrane receptors. The activation of EGFR receptors with their EGF ligand, present on the cell surface, promotes their dimerization, which is accompanied by phosphorylation of tyrosine residues, responsible for initiating signal transduction and the cascade of intracellular events, as well as for recruiting several enzymes and proteins responsible for cell proliferation and survival (CONTI et al., 2006).
EGF can act in several ways in the ovarian follicle: stimulating mitosis of granulosa and theca cells (CELESTINO et al., 2009), inducing oocyte growth (GALL et al., 2004), preserving follicular viability (CELESTINO et al., 2009), promoting steroid production (JAMNONGJIT et al., 2005), allowing the expansion of cumulus cells (BOLAMBA et al., 2006) and playing a preponderant role on nuclear and cytoplasmic maturation (HATOYA et al., 2009; PEREIRA et al., 2014). In addition, it has been observed in cattle that EGF can accelerate the extrusion time of the first polar corpuscle by increasing the activity of meiosis promoter factor (MPF) and mitogen-activated protein kinases (MAPK) (SAKAGUCHI et al., 2000). Supplementation of IVM medium with EGF at different concentrations $(1,10$, and $100 \mathrm{ng} / \mathrm{mL}$ ) stimulated the expansion of cumulus cells, increased the proportion of oocytes that reached M-II stage, and the rate of bovine embryos that reached the blastocyst stage (LONERGAN et al., 1996).

In bitches, high rates of M-II (18\%) were observed in oocytes obtained from the diestrus phase in medium supplemented with EGF when compared to medium without supplementation (1.3\%) (PEREIRA et al., 2014). Taking such information into account, the aim of this study was to evaluate the influence of EGF on the different times of in vitro maturation of canine oocytes.

\section{Material and Methods}

\section{Selection of ovaries and oocytes}

Ovaries of bitches were obtained from 55 bitches considered healthy at clinical examination, at different stages of the estrous cycle and of several breeds aged 1-7 years, which were submitted to elective ovariohysterectomy (OHE) (Figure 1A). Animals were obtained in castration campaigns for population control carried out in the municipalities of Sorocaba, Cotia, and Salto, inner state of São Paulo, Brazil. The use of animals for this research was approved by the Ethics Research Committee of the Faculty of Veterinary Medicine and Animal Science (FMVZUNESP) under protocol number 84/2015. Ovaries were aseptically isolated, immersed in physiological solution $(0.9 \% \mathrm{NaCl})$ and transported refrigerated to the Laboratory of Reproduction of Small and Wild Animals of FMVZ/ UNESP Campus Botucatu. They were then transferred to Petri dishes containing PBS (phosphate buffered saline), pH 7.2 (18\%) added of 10\% fetal bovine serum (FBS) (Figure 1B). Each ovary was sectioned with scalpel blades, 
along its length and width, for the release of cumulus-oocyte complexes (COCs) (Figure 1C). COCs were identified and quantified under stereomicroscope (Leica ${ }^{\circledR}$ MZ 12.5) and evaluated according to the homogeneity and color of the cytoplasm and number of cumulus cell layers, according to morphological criteria adopted by Hewitt and England (1997). Only grade 1 COCs were selected and washed three times in TCM-199 medium supplemented with 0.2 $\mathrm{mM}$ pyruvate, $20 \mathrm{mM}$ HEPES, $5 \mathrm{mM}$ sodium bicarbonate, $100 \mathrm{IU} / \mathrm{ml}$ penicillin and $100 \mathrm{mg} / \mathrm{ml}$ streptomycin.
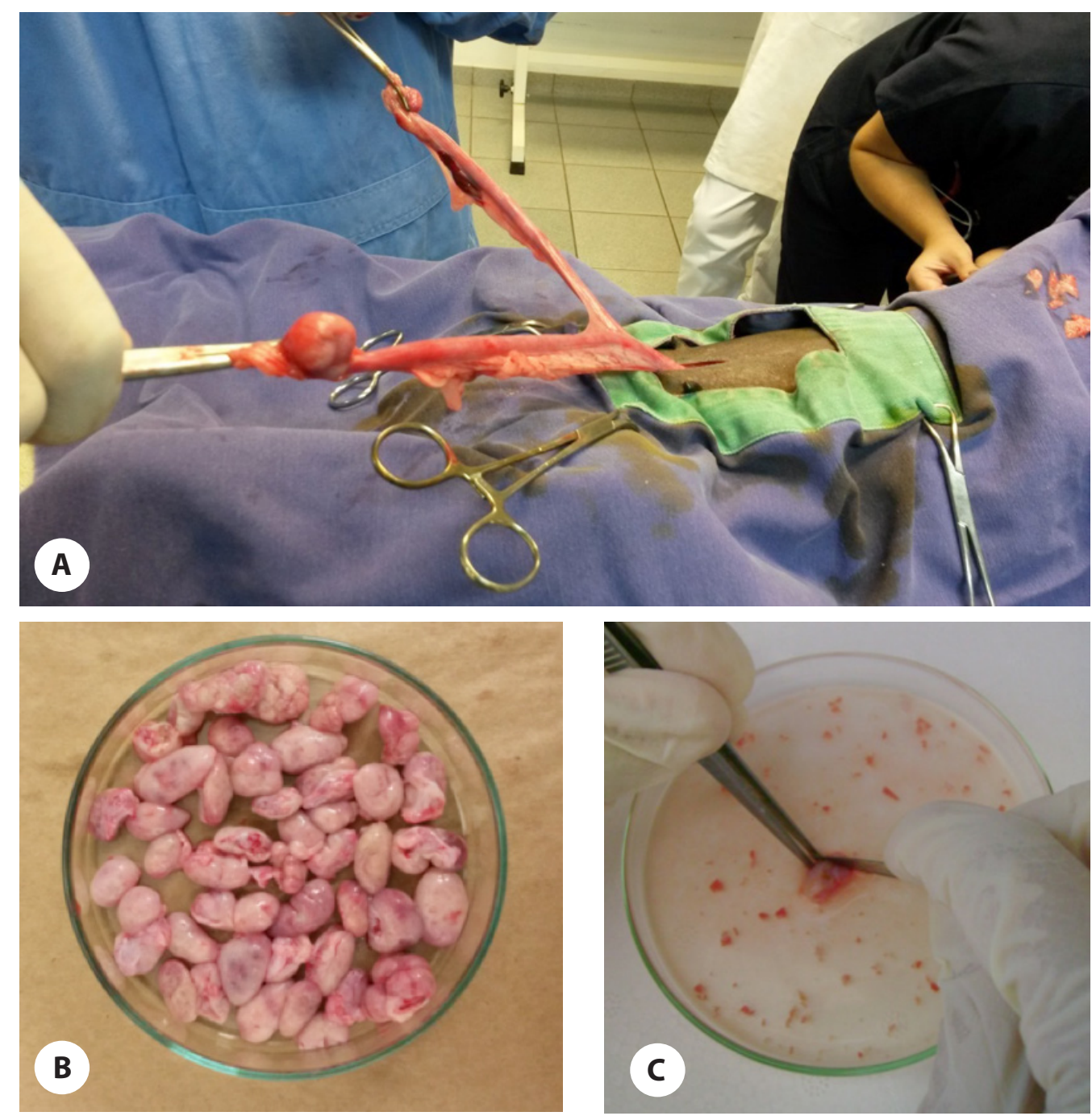

Figure 1 - (A) Ovary-salpinge-hysterectomy (OSH) performance (B) Ovaries collected from healthy bitches (C) Ovaries after the performance of the slicing method. Magnification of 40X. Botucatu, 2015

\section{In vitro oocyte maturation (IVM)}

The number of COCs retrieved was divided into two groups: control group (CG) and treatment group (TG). In CG 698 grade I COCs were plated in 4-well plates containing TCM-199 medium supplemented with 25 mM HEPES, 100 $\mathrm{IU} / \mathrm{mL}$ penicillin with $100 \mathrm{mg} / \mathrm{mL}$ streptomycin, $26 \mathrm{mM}$ sodium bicarbonate, $1.5 \mathrm{mM}$ sodium pyruvate, $2.9 \mathrm{mM}$ sodium lactate pentahydrate, $0.6 \mathrm{mM}$ cysteine, $0.03 \mathrm{IU} /$ $\mathrm{mL}$ hCG, $0.5 \mu \mathrm{g} / \mathrm{mL} \mathrm{FSH}, 20 \mu \mathrm{g} / \mathrm{mL}$ estrogen at $38.5^{\circ} \mathrm{C}$ in a humidified atmosphere of $5 \% \mathrm{CO}_{2}$ and remained under culture medium for $24 \mathrm{~h}, 48 \mathrm{~h}$, and $72 \mathrm{~h}$. In TG 547 grade 1
COCs were matured in the same maturation medium, but increased with $10 \eta \mathrm{g} / \mathrm{mL}$ epidermal growth factor (EGF) during the same periods of maturation previously described.

\section{Nuclear maturation evaluation}

COCs obtained from both groups were evaluated for nuclear maturation ( $24 \mathrm{~h}, 48 \mathrm{~h}$, and $72 \mathrm{~h}$ ). COCs were transferred to petri dishes containing $0.2 \%$ hyaluronidase solution for five minutes and with the aid of a $50 \mu \mathrm{L}$ pipette cumulus cells were removed (Figures $2 \mathrm{~A}$ and $2 \mathrm{~B}$ ). Then, oocytes were fixed in paraformaldehyde $(3.7 \%)$ 
for 20 minutes, washed again in PBS for inactivation of hyaluronidase and stained with a drop of bisbenzimide (Hoechst 33342), diluted in glycerol at concentration of $10 \mu \mathrm{g} / \mathrm{mL}$. Subsequently, oocytes were placed between slide and coverslip and evaluated under fluorescence microscope (Leica ${ }^{\circledR}$ DFC 310 FX). The classification of the nuclear oocyte maturation stage was performed according to DNA morphology: germinal vesicle (GV) (Figure 3A), germinal vesicle breakdown (GVBD) (Figure 3B), metaphase I (M-I) (Figure 3C), metaphase II (M-II) (Figure 3D), and degenerate or non-identifiable oocytes (Figure 3E) (HEWITT; ENGLAND, 1977).
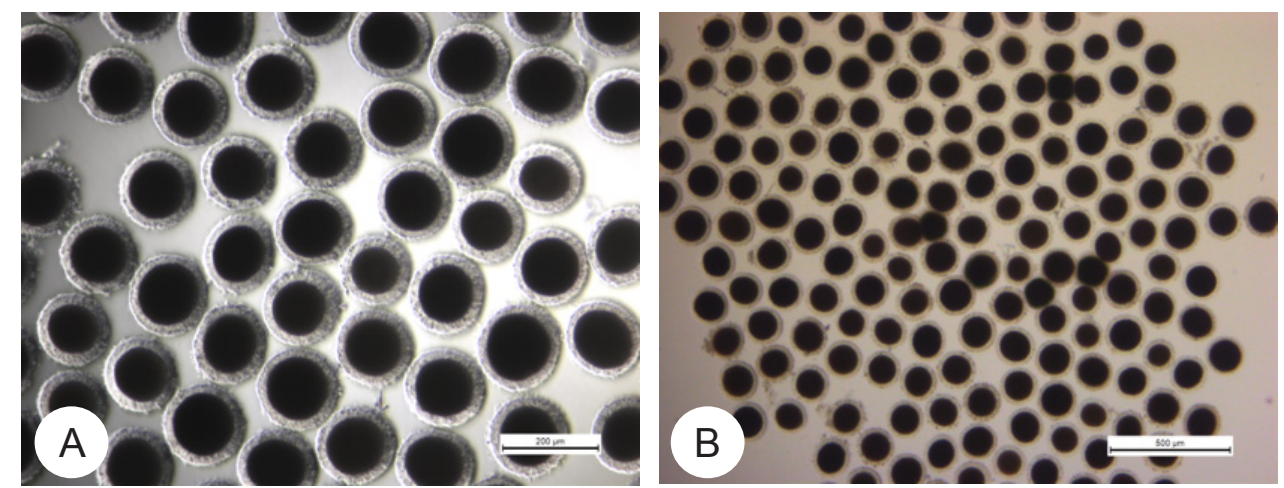

Figure 2 - (A) and (B) Oocytes treated with $0.2 \%$ hyaluronidase for the removal of cumulus cells. Inverted light microscope. (A) Magnification of 40X. (B) Magnification of 10X. Botucatu, 2015
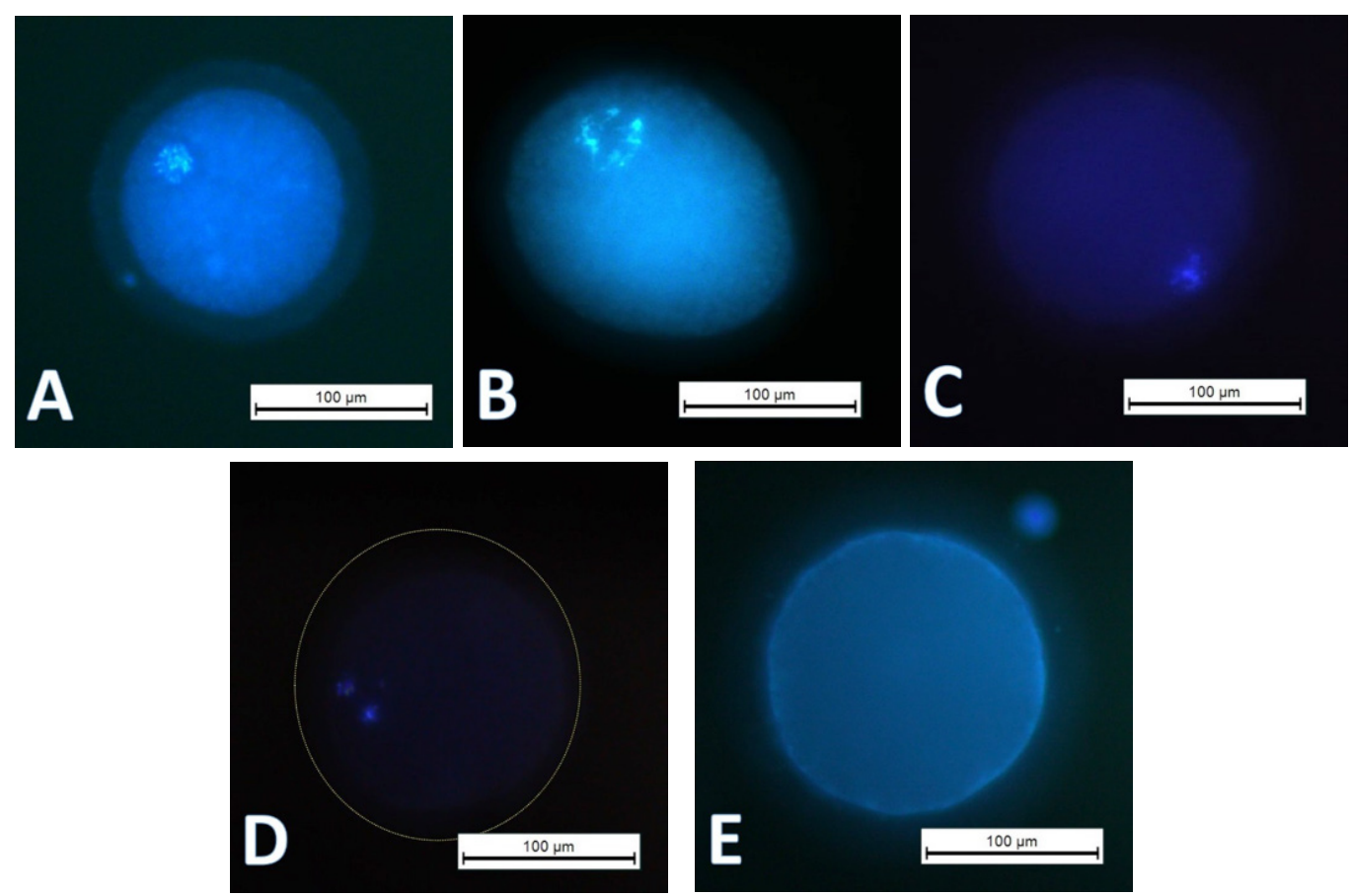

Figure 3 - Digital photomicrography of oocytes from bitches at different stages of nuclear maturation after in vitro culture. Evaluation and classification of chromatin. (A): Germinal vesicle (GV). (B): Germinal Vesicle Breakdown (GVBD), (C): Metaphase I (M-I). (D): Metaphase II (MII), (E): Degenerate or unable to be identified. Hoescht 33342 staining, wavelength 330-385 nm. Magnification of 200X. Botucatu, 2014

\section{Statistical Analysis}

Logistic regression models were constructed in order to estimate the chances of oocytes to be observed at germinal vesicle $(G V)$, germinal vesicle breakdown (GVBD), metaphase I (IM), metaphase II, and degenerate (DEG) maturation stages in different growing times $(24 \mathrm{~h}, 48 \mathrm{~h}$, and $72 \mathrm{~h}$ ).

\section{Results}

The chances of observing an oocyte at different maturation stages ( $24 \mathrm{~h}, 48 \mathrm{~h}$, and $72 \mathrm{~h}$ ) are presented in table 1, which shows that the chances of finding an oocyte in the GV stage at in time of 24 hour of IVM were 3.15 times greater than in $72 \mathrm{~h}(\mathrm{p}<0.0001)$. Similarly, the chances of having an oocyte at the GV stage were 2.4 times greater at $48 \mathrm{~h}$ when compared to 
$72 \mathrm{~h}(\mathrm{p}<0.0001)$. There was no difference $(\mathrm{p}>0.05)$ between groups regarding this stage (media with and without EGF). At 24 hours of IVM, there were 1.26 times more chances of an oocyte achieving GVBD stage than at time of $48 \mathrm{~h}$ ( $\mathrm{p}=$ $0.0002)$ and 1.42 times more chances than in 72 hours ( $\mathrm{p}=$ 0.0002 ). The culture medium without EGF supplementation was 3.66 times more likely to have an oocyte at GVBD stage than in medium supplemented with EGF ( $p=0.0002)$. By evaluating M-I stage, it was observed that the chances of finding an oocyte at $48 \mathrm{~h}$ of IVM were 2.7 times greater than in $24 \mathrm{~h}(\mathrm{p}<0.0001)$. The chances of finding an oocyte at M-I were also 3.12 times greater at $72 \mathrm{~h}$ of culture than at $24 \mathrm{~h}(\mathrm{p}<$ 0.0001). Medium supplemented with EGF demonstrated 2.56 times more chances of having an oocyte at M-I stage than the medium without EGF ( $\mathrm{p}<0.0001)$. Regarding the M-II stage, the time of $72 \mathrm{~h}$ showed 5.88 times more chances of having an oocyte than the $24 \mathrm{~h}$ of IVM ( $\mathrm{p}=0.0001)$ and 7.69 times more chance than in $48 \mathrm{~h}(\mathrm{p}=0.0001)$. The chances of finding an oocyte at M-II were also 9.09 times higher in medium supplemented with EGF than in the medium without EGF $(p=0.0001)$. The chances of obtaining a degenerate oocyte were 1.88 times greater in $72 \mathrm{~h}$ than in $24 \mathrm{~h}(\mathrm{p}<0.05)$, and 1.92 higher than in $48 \mathrm{~h}(\mathrm{p}<0.05)$. Medium added of EGF was 10 times more likely to have a degenerate oocyte than medium without supplementation ( $\mathrm{p}<0.05)$.

Table 1 - Odds ratio of finding an oocyte at different stages of nuclear maturation (GV: germinal vesicle, GVBD: germinal vesicle breakdown, M-I: metaphase I, M-II: metaphase and DEG: degenerate) at $24 \mathrm{~h}, 48 \mathrm{~h}$ and 72 $\mathrm{h}$ of in vitro culture medium supplemented with EGF

\begin{tabular}{|c|c|c|c|c|}
\hline $\begin{array}{l}\text { Variable } \\
\text { response }\end{array}$ & Culture time & $\mathbf{R C}$ & $\mathrm{Cl}(95 \%)$ & p-Value \\
\hline \multirow{9}{*}{ GV } & & & & $<0.0001$ \\
\hline & $24 \mathrm{~h}$ & 1.31 & $0.96-1.80$ & \\
\hline & $48 \mathrm{~h}$ & Reference & & \\
\hline & $24 \mathrm{~h}$ & 3.15 & $2.19-4.53$ & * \\
\hline & $72 \mathrm{~h}$ & Reference & & \\
\hline & $48 \mathrm{~h}$ & 2.40 & $1.65-3.50$ & * \\
\hline & $72 \mathrm{~h}$ & Reference & & \\
\hline & WITHOUT EGF & 1.0 & $0.74-1.30$ & \\
\hline & WITH EGF & Reference & & \\
\hline \multirow{9}{*}{ GVB } & & & & 0.0002 \\
\hline & $24 \mathrm{~h}$ & 1.36 & $1.02-1.82$ & * \\
\hline & $48 \mathrm{~h}$ & Reference & & \\
\hline & $24 \mathrm{~h}$ & 1.42 & $1.06-1.91$ & * \\
\hline & $72 \mathrm{~h}$ & Reference & & \\
\hline & $48 \mathrm{~h}$ & 1.05 & $0.78-1.41$ & \\
\hline & $72 \mathrm{~h}$ & Reference & & \\
\hline & WITHOUT EGF & 3.66 & $2.88-4.65$ & * \\
\hline & WITH EGF & Reference & & \\
\hline
\end{tabular}

Table 1 - Continuation

\begin{tabular}{|c|c|c|c|c|}
\hline $\begin{array}{l}\text { Variable } \\
\text { response }\end{array}$ & Culture time & RC & $\mathrm{Cl}(95 \%)$ & p-Value \\
\hline & & & & $<0.0001$ \\
\hline & $24 \mathrm{~h}$ & 0.37 & $0.25-0.56$ & * \\
\hline & $48 \mathrm{~h}$ & Reference & & \\
\hline & $24 \mathrm{~h}$ & 0.32 & $0.22-0.48$ & * \\
\hline \multirow[t]{9}{*}{ M-I } & $72 \mathrm{~h}$ & Reference & & \\
\hline & $48 \mathrm{~h}$ & 0.86 & $0.62-1.20$ & \\
\hline & $72 \mathrm{~h}$ & Reference & & \\
\hline & WITHOUT EGF & 0.39 & $0.29-0.53$ & * \\
\hline & WITH EGF & Reference & & \\
\hline & & & & 0.0001 \\
\hline & $24 \mathrm{~h}$ & 1.25 & $0.28-5.64$ & \\
\hline & $48 \mathrm{~h}$ & Reference & & \\
\hline & $24 \mathrm{~h}$ & 0.17 & $0.06-0.49$ & * \\
\hline \multirow[t]{9}{*}{ M-II } & $72 \mathrm{~h}$ & Reference & & \\
\hline & $48 \mathrm{~h}$ & 0.13 & $0.04-0.45$ & * \\
\hline & $72 \mathrm{~h}$ & Reference & & \\
\hline & WITHOUT EGF & 0.11 & $0.04-0.32$ & * \\
\hline & WITH EGF & Reference & & \\
\hline & & & & 0.01 \\
\hline & $24 \mathrm{~h}$ & 1.02 & $0.55-1.88$ & \\
\hline & $48 \mathrm{~h}$ & Reference & & \\
\hline & $24 \mathrm{~h}$ & 0.53 & $0.31-0.91$ & * \\
\hline \multirow[t]{5}{*}{ DEG } & $72 \mathrm{~h}$ & Reference & & \\
\hline & $48 \mathrm{~h}$ & 0.52 & $0.30-0.90$ & * \\
\hline & $72 \mathrm{~h}$ & Reference & & \\
\hline & WITHOUT EGF & 0.10 & $0.05-0.18$ & * \\
\hline & WITH EGF & Reference & & \\
\hline
\end{tabular}

\section{Discussion}

In bitches the lack of an adequate culture medium that meets their biochemical and endocrine needs makes it impossible to develop reproductive biotechnologies for this animal species. Thus, the selection of media containing protein, hormone, antioxidant, and growth factors supplements is essential for the efficacy of in vitro maturation. Among the growth factors used in vitro, EGF has been highlighted as an important component to promote the acquisition of oocyte competence in this species. The results of this study demonstrated that the addition of EGF is benefic for the progression of maturation and complete meiotic development, which allows oocytes to reach the M-II stage.

EGF is a factor that has been widely used in order to promote optimal conditions for the development of oocytes and in vitro cultured embryos. Buyalos and Cai (1994) found a positive effect of EGF on embryonic development due to its specific mitogenic effects. In a study conducted by Baştan et al. (2010), cumulus cell expansion and nuclear maturation rates of bovine oocytes were significantly higher when medium was supplemented with EGF, regardless of 
the concentration (1, 10 or $100 \mathrm{ng} / \mathrm{mL})$, when compared to medium without EGF. Pereira et al. (2015) also observed a significant increase $(\mathrm{p}<0.05)$ of oocytes that reached metaphase stage II (M-II) obtained from diestrous bitches, cultured with $10 \mathrm{ng} / \mathrm{mL}$ of EGF. In this study the chances of finding an oocyte at M-II stage were 9.09 times higher in medium supplemented with EGF than in medium without EGF ( $p=0.0001)$, and $72 \mathrm{~h}$ is the ideal time for the oocyte to reach the final stages of nuclear maturation.

Guller et al. (2000) found a significant increase (84\%) in sheep oocytes at M-II stage after $24 \mathrm{~h}$ of culture in medium supplemented with EGF when compared to medium without EGF (59\%). The cleavage rate after 2 days of culture was significantly higher $(\mathrm{p}<0.001)$ in medium with EGF supplementation (29\% versus 19\%). In this study, regarding the M-II stage, it was observed that the time of $72 \mathrm{~h}$ showed 5.88 times more chances of having an oocyte at this stage than the time of $24 \mathrm{~h}(\mathrm{p}=0.0001)$ and 7.69 times more chances than the time of $48 \mathrm{~h}(\mathrm{p}=0.0001)$. These differences related to the culture time reflect peculiar and unique physiological aspects of reproduction that are only observed to date in bitches. In the canine species, as observed in this study, even after $48 \mathrm{~h}$ of culture, oocytes can be observed at GV and GVBD stages. However, based on the results, it was observed that this index is even higher when medium is not supplemented with EGF. Medium supplemented with EGF showed 2.56 times more chances of having an oocyte at M-I stage than medium without EGF ( $p<0.0001$ ), while the chances of finding an oocyte at M-II were also 9.09 times higher in medium supplemented with EGF than in medium without EGF ( $p=0.0001)$.

In species such as swine, primates, and rodents the proestrus phase is associated with follicle stimulating hormone (FSH) secretion, which promotes follicular growth and increases the estrogen and progesterone concentrations produced by granulosa cells, which reaches maximum peak from $24 \mathrm{~h}$ to $48 \mathrm{~h}$ before the onset of estrus. In these species the change from proestrus to estrous phase is characterized by a hormonal inversion, represented by a decline in estradiol levels and an increase in progesterone concentration. This phenomenon is called preovulatory luteinization, which is not observed in the canine species. In canids follicular cells undergo luteinization 60-70 $\mathrm{h}$ before ovulation, and pre-ovulatory progesterone increase occurs immediately before or simultaneously with the luteinizing hormone (LH) peak. Spontaneous ovulation in bitches starts $48 \mathrm{~h}$ after the LH surge, and the oocyte is released still immature in the GV stage and completes the meiotic maturation in the oviduct, about $54 \mathrm{~h}$ to $72 \mathrm{~h}$ after ovulation (CONCANNON et al., 1989). Thus, bitches require a longer period of in vitro culture so that oocytes acquire the ability to reach the M-II stage when compared to other domestic species. This higher culture period was observed in this study in which the time of $72 \mathrm{~h}$ was the most adequate to obtain oocytes at the final maturation stages.

EGFR is expressed both in cumulus cells and oocytes and its expression is associated with meiotic competence. However, events related to the resumption of EGFRmediated meiosis are not yet well elucidated. mRNA encoding the EGF protein and receptor (EGFR) was identified in the oocyte and in granulosa cells of early follicles and those in advanced development stages, in several species such as female rats (FENG et al., 1987), humans (QU et al., 2000), cows (LONERGAN et al., 1996), hamsters (GARNETT et al., 2002), and goats (SILVA et al., 2006). However, in bitches the EGF receptor protein (EGFR) was undetectable in cumulus cells and oocytes (SONG et al., 2011). New investigations are needed regarding the canine species in order to better understand the influence of EGF on cell signaling pathways. According to the results of this study, EGF seems to play a determinant role in different moments of in vitro oocyte maturation, influencing the transition from M-I to M-II stages. Regardless of culture time, there was no influence of EGF on the GV stage; however, it was observed that this supplementation promoted a difference in GVBD, M-I, and M-II indexes. When compared to medium without supplementation, medium with EGF obtained higher M-I and M-II indexes at different culture times, which demonstrates the importance of this factor for the meiosis resumption and the ability of the oocyte to complete nuclear maturation.

EGFR receptor is a transmembrane glycoprotein and its signaling occurs via different tyrosine kinase-linked transmembrane receptors that have monomeric (VEGFR, IGFR, and GAS6) and dimeric structures formed by homodimers (EGFR-EGFR, Her2-Her2, Her3-Her3) and dimeric structures formed by heterodimers (EGFRHer3, Her2-Her3, Met-Her3). This receptor together with its multiple ligands is considered the major regulator of several reproductive processes that control cell division and differentiation (SCHNEIDER; WOLF, 2009). EGFR exists as an inactive monomer that is activated via an external ligand. This leads the receptor to dimerize with another 
EGFR monomer or with another member of the receptor family. EGFR dimerization induces the catalytic tyrosine kinase activity, which leads to autophosphorylation at various tyrosine sites. Phosphotyrosines resulting from this process act as anchoring sites for signal transducing enzymes and adaptation proteins that will unchain cellular effects (WELLS, 1999). These adapter proteins may have multiple binding sites that induce the activation of a complex network of signaling patterns, i.e., transduction pathways.

Little is known about the signaling mechanisms responsible for meiosis resumption and the signaling pathways coordinated by EGF in bitches. Although these mechanisms are well understood in other domestic species, in the canine species the mRNA for the EGF protein and its EGFR receptor have not yet been detected and, therefore, there is no information about the regulatory processes coordinated by these proteins and their consequences in the various processes such as cell division, differentiation, and apoptosis. According to De Moor and Richter (2001), oocyte proteins need to be activated after translational modifications. The growing oocyte accumulates a large amount of RNA - however, most of the transcribed mRNAs remain in the ooplasm in the translationally inactive form, being activated after a series of phosphorylation and dephosphorylation processes. Thus, the protein for EGF and its EGFR receptor may not have been identified in the canine species due to the fact that mRNA is present in the inactive form in the cell, which raises the need for further studies focused on the translational modifications in this species, as well as the signaling pathways that are responsible for cell cycle coordination and acquisition of meiotic competence.

According to Hynes and Macdonald (2009), when there is imbalance between growth factors and their respective membrane receptors, abnormal signaling occurs. The two major cascades of reactions that are affected in EGFR signaling are those of Akt and Ras. RAS genes act as "molecular switches" in the transmission pathways of biological signals of their own pathway (Ras Signaling) and other pathways (GCPR, Wnt, AKT, and TGF $\beta$ ), regulating the activation or deactivation of mRNA transcription and translation, the transit of inducers through the cytoplasmic membrane, as well as cell division differentiation, adhesion, migration, cell cycle disruption, and apoptosis. Thus, it could be inferred that alterations caused in the signaling cascade by EGFR may have influenced the Ras cascade and consequently altered cell processes, which can be verified by the high rates of cellular degeneration observed in cultured oocytes in the group treated with EGF.

Chen et al. (2008) reported that cumulus cells are important for the activation of EGFR in oocytes via kinase $\mathrm{C}$ protein. As the gap junctions mediating the communication of cumulus cells and oocytes are essential for meiosis resumption, it is possible that the positive signals cells from EGF are generated by cumulus cells and transmitted to oocytes by these junctions to promote meiotic resumption. In this context cumulus cells are an indispensable factor for in vitro maturation. Changes in the gap junctions according to the phase of the estrous cycle have been observed in bitches. According to Luvoni et al. (2001) cumulus-oocyte complexes (COCs) obtained from anestrous bitches have closed gap junctions, while at the end of proestrus $89 \%$ of these junctions are open. According to these authors, oocytes obtained during anestrus would have low potential to reach M-II due to the lack of communication between somatic cells and the oocyte, making it impossible to transport molecules between these cellular patterns. Pereira et al. (2014) corroborated these results, showing that the chances of finding an oocyte at M-II stage are 1.9 (1.04-3.46) times higher in ovaries obtained in diestrus $(\mathrm{p}<0.05)$. Thus, as gap junctions are essential for the activation of EGFR, it is possible that in bitches, depending on the reproductive status, the signaling mechanism for the effects of EGF occur through different pathways. In canids the binding of EGF to its receptor may not be necessary for its effects to be active in oocyte development. Uhm et al. (2010) observed that although EGFR expression occurred in oocytes and cumulus cells of pigs, EGF had no effect on nuclear maturation. These results corroborate the hypothesis that the activation or expression of EGFR may not be necessary for the acquisition of meiotic competence. This is the first description of the effect of EGF supplementation at different times of in vitro maturation, demonstrating that this growth factor plays a key role in canine oocyte development, being essential for the oocyte to be able to be fertilized.

The culture time required for complete oocyte maturation varies according to the species studied and reproductive specificities. In humans COCs cultured in medium containing EGF and IFG-I growth factors had a significant increase $(\mathrm{p}<0.05)$ in the percentage of oocytes at M-II stage after $24 \mathrm{~h}$ and $48 \mathrm{~h}$ of in vitro culture (GÓMEZ et al., 1993). A study with oocytes of female rats (AMIRI et 
al., 2009) demonstrated a significant $(\mathrm{p}<0.01)$ stimulatory effect of EGF on maturation after $24 \mathrm{~h}$ of culture and on embryonic development. The addition of EGF in the culture medium promoted higher cleavage and blastocyst formation rates. In our study the chances of finding an oocyte at M-I were 3.12 times greater with $72 \mathrm{~h}$ of culture than with $24 \mathrm{~h}(\mathrm{p}<0.0001)$. Regarding the M-II stage, the time of $72 \mathrm{~h}$ showed 5.88 times more chances of having an oocyte at this stage than the time of $24 \mathrm{~h}(\mathrm{p}=0.0001)$ and 7.69 times more chances than the time of $48 \mathrm{~h}(\mathrm{p}=$ 0.0001). In the different times of in vitro maturation EGF influenced the meiosis resumption and nuclear progression of the oocyte. Even with high rates of oocyte degeneration, EGF supplementation promotes positive results in nuclear maturation. These results show that the time of $72 \mathrm{~h}$ reflects the optimum culture time to optimize oocyte maturation. These results corroborate the fact that oocytes in bitches are ovulated still at the immature stage, needing after ovulation from 2 to 5 days to complete maturation (YAMADA et

\section{References}

AMIRI, I.; MIRAHADI, N.; AMINI, A.; PARVINI, M.; HEIDARBIGI, K. H. The effects of LIF and EGF on mouse oocyte maturation, fertilization and development in vitro. Iranian Journal of Reproductive Medicine, v. 7, n. 4, p. 189-194, 2009.

BAŞTAN, A.; POLAT, B.; BAKİ ACAR, D.; KORKMAZ, O.; ÇOLAK, A. Determination of optimal dose of EGF for bovine oocyte maturation and subsequent in vitro fertilization and culture in two media. Turkish Journal of Veterinary and Animal Sciences, v. 34, n. 1, p. 33-38, 2010. doi: 10.3906/vet-0711-23.

BOLAMBA, D.; RUSS, K. D.; HARPER, S. A.; SANDLER, J. L.; DURRANT, B.S. Effects of epidermal growth factor and hormones on granulosa expansion and nuclear maturation of dog oocytes in vitro. Theriogenology: an International Journal of Animal Reproduction, v. 65, n. 6, p. 1037-1047, 2006. doi: 10.1016/j.theriogenology.2005.06.017.

BOLAMBA, D.; RUSS, K. D.; OLSON, M. A.; SANDLER, J. L.; DURRANT, B. S. In vitro maturation of bitch oocytes from advanced preantral follicles in synthetic oviduct fluid medium: serum is not essencial. Theriogenology: al., 1992). In this context EGF seems to be necessary for competence acquisition since the chances of obtaining oocytes at M-I and M-II stages were higher in the groups supplemented with this growth factor.

\section{Conclusion}

The results of this work demonstrated the importance of EGF at different moments of oocyte maturation, being an essential component for the acquisition of meiotic competence in bitches, which demonstrated increasing M-I and M-II indexes. However, the signaling pathways responsible for the cell cycle and apoptosis, as well as the expression and activation of EGFR should be further studied to better understand the biological mechanisms of this species.

\section{Funding sources}

São Paulo Research Foundation - FAPESP, number 2013/21667-3 and 2014/19776-1.

an International Journal of Animal Reproduction, v. 58, n. 9, p. 1689-1703, 2002. doi: 10.1016/S0093-691X(02)01080-4.

BUYALOS, R. P.; CAI, X. Preimplantation embryo development enhanced by epidermal growth factor. Journal of Assisted Reproduction and Genetics, v. 11, n. 1, p. 33-37, 1994. doi: 10.1007/BF02213695.

CELESTINO, J. J. H.; BRUNO, J. B.; LIMA-VERDE, I. B.; MATOS, M. H. T.; SARAIVA, M. V. A.; CHAVES, R. N.; MARTINS, F. S.; LIMA, L. F.; NAME, K. P. O.; CAMPELLO, C. C.; SILVA, J. R. V.; BÁO, S. N.; FIGUEIREDO, J. R. Recombinant epidermal growth factor maintains follicular ultrastructure and promotes the transition to primary follicles in caprine ovarian tissue cultured in vitro. Reproductive Sciences, v. 16, n. 3, p. 239-246, 2009. doi: 10.1177/1933719108325756.

CHEN, X.; ZHOU, B.; YAN, J.; XU, B.; TAI, P.; LI, J.; PENG, S.; ZHANG, M.; XIA, G. Epidermal growth factor receptor activation by protein kinase $\mathrm{C}$ is necessary for FSH-induced meiotic resumption in porcine cumulusoocyte complexes. Journal of Endocrinology, v. 197, n. 2, p. 409-419, 2008. doi: 10.1677/JOE-07-0592. 
CONCANNON, P. W.; MCCANN, J. P.; TEMPLE, M. Biology and endocrinology of ovulation, pregnancy and parturition in the dog. Journal of Reproduction and Fertility Supplement, v. 39, p. 3-25, 1989.

CONTI, M.; HSIEH, M.; PARK, J.-Y.; SU, Y.-Q. Role of the epidermal growth factor network in ovarian follicles. Molecular Endocrinology, v. 20, n. 4, p. 715-723, 2006. doi: 10.1210/me.2005-0185.

DE MOOR, C. H.; RICHTER, J. D. Translational control in vertebrate. International Review of Cytology, v. 203, p. 567-608, 2001. doi: 10.1016/S0074-7696(01)03017-0.

FARSTAD, W. Assisted reproductive technology in canid species. Theriogenology: an International Journal of Animal Reproduction, v. 53, n. 1, p. 175-186, 2000. doi: 10.1016/S0093-691X(99)00250-2.

FENG, P.; KNECHT, M.; CATT, K. Hormonal control of epidermal growth factor receptors by gonadotropins during granulosa cell differentiation. Endocrinology, v. 120, n. 3, p. 1121-1126, 1987. doi: 10.1210/endo-120-3-1121.

GALL, L.; CHENE, N.; DAHIREL, M.; RUFFINI, S.; BOULESTEIX, C. Expression of epidermal growth factor receptor in the goat cumulus-oocyte complex. Molecular Reproduction and Development, v. 67, n. 4, p. 439-445, 2004. doi: 10.1002/mrd.20040.

GARNETT, K.; WANG, J.; ROY, S. K. Spatiotemporal expression of epidermal growth factor receptor messenger RNA and protein in the hamster ovary: follicle stage-specific differential modulation by folliclestimulating hormone, luteinizing hormone, estradiol, and progesterone. Biology of Reproduction, v. 67, n. 5, p. 15931604, 2002. doi: 10.1095/biolreprod.102.005470.

GÓMEZ, E.; TARÍN, J. J.; PELLICER, A. Oocyte maturation in humans: the role of gonadotropins and growth factors. Fertility and Sterility, v. 60, n. 1, p. 4046, 1993. doi: 10.1016/S0015-0282(16)56033-6.

HATOYA, S.; SUGIYAMA, Y.; NISHIDA, H.; OKUNO, T.; TORII, R.; SUGIURA, K.; KIDA, K.; KAWATE, N.; TAMADA, H.; INABA, T. Canine oocyte maturation in culture: significance of estrogen and EGF receptor gene expression in cumulus cells. Theriogenology: an International Journal of Animal Reproduction, v. 71, n. 4, p. 560-567, 2009. doi: 10.1016/j.theriogenology.2008.08.013.

HEWITT, D. A.; ENGLAND, G. C. W. Effect of preovulatory endocrine events upon maturation of oocytes of the domestic bitches. Journal of Reproduction and Fertility Supplement, v. 51, p. 83-91, 1997.

HYNES, N. E.; MACDONALD, G. ErbB receptors and signaling pathways in cancer. Current Opinion in Cell Biology, v. 21, n. 2, p. 177-184, 2009. doi: 10.1016/j. ceb.2008.12.010.

JAMNONGJIT, M.; GILL, A.; HAMMES, S. R. Epidermal growth factor receptor signaling is required for normal ovarian steroidogenesis and oocyte maturation. Proceedings of the National Academy of Sciences of the United States of America, v. 102, n. 45, p. 16257-16262, 2005. doi: 10.1073/pnas.0508521102.

KIM, M. K.; FIBRIANTO, Y. H.; OH, H. J.; JANG, G.; KIM, H. J.; LEE, K. S.; KANG, S. K.; LEE, B. C.; HWANG, W. S. Effect of $\beta$-mercaptoethanol or epidermal growth factor supplementation on in vitro maturation of canine oocytes collected from dogs with different stages of the estrus cycle. Journal of Veterinary Science, v. 5, n. 3, p. 253-258, 2004.

LONERGAN, P.; CAROLAN, C.; VANLANGENDONCKT, A.; DONNAY, I.; KHATIR, H.; MERMILLOD, P. Role of epidermal growth factor in bovine oocyte maturation and preimplantation embryo development in vitro. Biology of Reproduction, v. 54, n. , p. 1420-1429, 1996. doi: 10.1095/ biolreprod54.6.1420.

LUVONI, G. C.; LUCIANO, A. M.; MODINA, S.; GANDOLFI, F. Influence of different stages of the oestrous cycle on cumulus-oocyte communications in canine oocytes: effects on the efficiency of in vitro maturation. Journal of Reproduction and Fertility Supplement, v. 57, p. 141-146, 2001.

PEREIRA, L. M. C.; BERSANO, P. R. O.; LIMA, A. F. M.; PANTOJA, J. C. F.; LOPES, M. D. Influência das fases de anestro e diestro na competência meiótica oocitária de cadelas Brazilian Journal of Veterinary Research and 
Animal Science, v. 52, n. 3, p. 266-272, 2015. doi: 10.11606/ issn.1678-4456.v52i3p266-272.

PEREIRA, L. M. C.; BERSANO, P. R. O.; LOPES, M. D. Efeito do fator de crescimento epidermal (EGF) na maturação in vitro de oócitos caninos. Brazilian Journal of Veterinary Research and Animal Science, v. 51, n. 2, p. 158-165, 2014. doi: 10.11606/issn.1678-4456.v5li2p158-165.

QU, J.; GODIN, P. A.; NISOLlE, M.; DONNEZ, J. Distribution of epidermal growth factor receptor expression of primordial follicles in human ovarian tissue before and after cryopreservation. Human Reproduction, v. 15, n. 2, p. 302-310, 2000. doi: 10.1093/humrep/15.2.302.

SAKAGUCHI, M.; DOMINKO, T.; LEIBFRIEDRUTLEDGE, M. L.; NAGAI, T.; FIRST, N. L. A combination of EGF and IGF-I accelerates the progression of meiosis in bovine follicular oocytes in vitro and fetal calf serum neutralizes the acceleration effect. Theriogenology: an International Journal of Animal Reproduction, v. 54, n. 8, p. 1327-1342, 2000. doi: 10.1016/ s0093-691x(00)00439-8.

SCHNEIDER, M. R.; WOLF, E. The epidermal growth factor receptor ligands at a glance. Journal of Cellular Phisiology, v. 218, n. 3, p. 460-466, 2009. doi: 10.1002/ jcp.21635.
SILVA, J. R. V.; VAN DEN HURK, R.; FIGUEIREDO, J. R. Expression of mRNA and protein localization of epidermal growth factor and its receptor in goat ovaries. Zygote, v. 14, n. 2, p. 107-117, 2006. doi: 10.1017/S0967199406003650.

SONG, H. J.; KANG, E. J.; MAENG, G. H.; OCK, S. A.; LEE, S. L.; YOO, J. G.; JEON, B. G.; RHO, G. J. Influence of epidermal growth factor supplementation during in vitro maturation on nuclear status and gene expression of canine oocytes. Research in Veterinary Science, v. 91, n. 3, p. 439-445, 2011. doi: 10.1016/j.rvsc.2010.09.003.

UHM, S. J.; GUPTA, M. K.; YANG, J. H.; CHUNG, H. J.; MIN, T. S.; LEE, H. T. Epidermal growth factor can be used in lieu of follicle-stimulating hormone for nuclear maturation of porcine oocytes in vitro. Theriogenology: an International Journal of Animal Reproduction, v. 73, n. 8, p. 1024-1036, 2010. doi: 10.1016/j.theriogenology.2009.11.029.

WELLS, A. EGF receptor. The International Journal Biochemistry \& Cell Biology, v. 31, n. 6, p. 637-643, 1999. doi: 10.1016/S1357-2725(99)00015-1.

YAMADA, S.; SHIMAZU, Y.; KAWAJI, H.; NAKAZAWA, M.; NAITO, K.; TOYODA, Y. Maturation, fertilization, and development of dog oocytes in vitro. Biology of Reproduction, v. 46, n. 5, p. 853-858, 1992. doi: $10.1095 /$ biolreprod46.5.853. 